\title{
Wathint' Umfazi, Wathint' Imbokodo, Uzakufa [You Strike a Woman, You Strike a Rock, You Will Die]: Dinah and Tamar as rape protestors
}

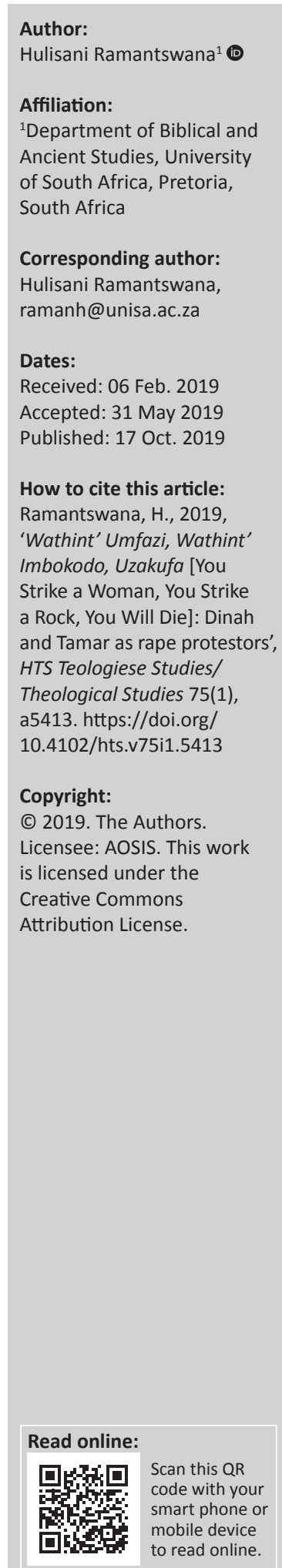

This article reflects on two rape stories, namely, the rape of Dinah and the rape of Tamar. In the two rape stories, the male figures are portrayed as heroes - the defenders of the rape victims. However, this article uses the isiZulu saying 'Wathint'umfazi, wathint' imbokodo, uzakufa' to foreground the role of the rape victims as the unsung heroines in the stories. Thus, the paper presents Dinah and Tamar as heroines, who represent the demand for justice in the face of the violation of female bodies in society. It is the woman's voice of protest that should be heard in each of the rape story crying out, 'My life matters!'

Keywords: Rape; Dinah; Tamar; Androcentric; Gynocentric; Protest; Feminist.

\section{Introduction}

It has been 5 years since she was raped as she walked from Sunday church service in Tembisa township. It all happened unexpectedly, when a man came from behind, pointed a gun at her and instructed her to keep on walking or else she would die. Terrified for her own life, she kept on walking as directed to a nearby area away from people's sight, where he raped her. Her rapist was not caught, and the thought of him still on the loose is spine-chilling. She has overcome much of the trauma, but the scars remain. Every year in February, she recalls the violation of her body. She calls her pastor and says, 'It was on this day that it happened'. She cannot even name what happened because the pain that it brought is beyond naming. ${ }^{1}$

In this article, I reflect on two rape stories, the rape of Dinah (Gn 34) and the rape of Tamar (2 Sm 13). In the world as projected by the canonical story, the two rape stories are many generations apart. In this study, the two stories would be read in dialogue with each other as stories that mutually enrich each other. A dialogic reading of biblical texts refuses to limit the meaning of the text to the original meaning of the author, as that limits the biblical text to its historical epoch. I follow Bakhtin's view that texts have potential intentionality or meaning potential that cannot be limited to the authorial intention/meaning (Bakhtin 1981).

In the two rape stories, the male figures, specifically the brothers of the victims, are portrayed as heroes - the defenders of the victims. However, this article claims that it is more rational to understand the women in the rape stories as the unsung heroines in the stories, not simply as passive objects. I reflect on these two stories through the lens of the isiZulu saying Wathint' umfazi, wathint' imbokodo, uzakufa [You strike a woman, you strike a rock, you will die] to foreground the role of the rape victims as the unsung heroines. Thus, the article presents Dinah and Tamar as heroines who represent the demand for justice in the face of the violation of female bodies in society. It is the woman's voice of protest that should be heard in each of the rape stories crying out, 'My life matters!'

\section{Wathint' Umfazi, Wathint' Imbokodo, Uzakufa}

The isiZulu saying Wathint' umafazi, wathint' imbokodo, uzakufa became popular during the apartheid era, and it came to represent the courage of women to resist the unjust pass laws of the time. ${ }^{2}$ 1.The rape incident outlined in this paragraph was used with permission from the victim of the rape.
2.In the Zulu culture, the term imbokodo is used for a 'grinding stone' - a resistant and durable stone mainly used by women in the
household for processing materials through pounding and pestling. As Nzimande (2008:223) in her book chapter entitled 'Reconfiguring
Jezebel: A Postcolonial Imbokodo Reading of the Story of Naboth's Vineyard ( $1 \mathrm{Ki} 21: 1-16)^{\prime}$ ' notes, 'imbokodo symbolises unity,
solidarity and strength. Imbokodo is dependable: no matter what the task, it remains intact and unscathed'. See also her PhD
dissertation, 'Postcolonial Biblical Interpretation in Post-Apartheid South Africa: The Gebirah in the Hebrew Bible in the Light of Queen
Jezebel and the Queen Mother Lemuel' (PhD dissertation, Brite Divinity School, Texas Christian University, 2005).

Note: The collection entitled 'Christina Landman Festschrift', sub-edited by Wessel Bentley (University of South Africa) and Victor S. Molobi (University of South Africa). 
On 09 August 1956 over 20000 women, the majority of whom were black women, marched to the Union Building in protest against the unjust Urban Areas Act. This march was not the first of its kind: in 1913, black women in the Orange Free State protested against the pass laws of the time, considering the horrendous treatment they were receiving at the time that undermined their human dignity and inferiorised them (Cock 1991; Gouws \& Kadalie 1994; Kaim 1978; Kros 1978; Meintjes 1996; Obery 1980; Walker 1978, 1991; Wells 1993). The Federation of South African Women (FSAW) expressed its struggle as follows:

As wives and mothers we condemn the pass laws and all they imply; Women are not afraid of suffering for the sake of their children and their homes. Women have an answer to the threats to their families and their future. Women will not face a future imprisoned in the pass laws. (as quoted from Cock 1991)

The saying Wathint' umfazi, wanthint' imbokodo came to be more than just a saying; it became a freedom song. In singing the song, the perpetrators of injustice would be named. For example, in the 1956 march, the women named the prime minister: Strijdom, Wathint' abafazi, wathint' imbokodo, uzakufa [Strijdom, you struck women, you have struck a rock, you will die]. The perpetrators of injustice had to be named and shamed. Mama Albertina Sisulu recalled the events of that day (as quoted from Pollard III 1999):

I could not believe it when I arrived. There was a sea of women, a huge mass, oh, it was wonderful. We were so excited. We couldn't believe we were there, and so many of us. Our leaders, Lilian Ngoyi, Helen Joseph, Sophi Williams, and Rahima Moosa attempted to give our protests to the prime minister, J. G. Strijdom, but when we got there, he'd left, he'd run away. [...] When the four women returned, we stood in silent protest for thirty minutes and then started singing Nkosi Sikeleli Afrika. Twenty thousand women singing Nkosi Sikeleli Afrika, you should have heard the echoes in the Union Building. There was nothing like that sound, it filled the world. Then we sang a song of the women, Strijdom, wathint' abafazi, wathint' imbokodo, uzakufa - Strijdom, you have tampered with the women, you have struck a rock, you have unleashed a boulder, you will die. (p. 104)

The naming and shaming of Strijdom in the song were not directed merely to Strijdom as an individual but as a representative of an oppressive state. As Gilbert (2005) also notes, during the apartheid period, the freedom songs tended to name the targets of their resistance - general name, Boers, and also specific names such as Vorster and Verwoerd as representatives of the state.

The involvement of the women in the struggle for freedom meant that, like their male counterparts, they needed to harden themselves like rocks so that the apartheid machinery would not break them, but they would break it. The females' bodies, unlike their male counterparts who were taken to Robben Island as political prisoners, had to bear the brutal force of the apartheid state, which disenfranchised their families, tortured and violated their bodies. It is no wonder that there is a song that particularly praises the women of South Africa:

Igama lamakosikazi, malibongwe

malibongwe, malibongwe. ${ }^{3}$

In singing this song, the names of the heroines would also be inserted. For example:

Igama le ka comrade Winnie, malibongwe,

malibongwe, malibongwe. ${ }^{4}$

In this case, then, naming is meant to praise rather than to shame the struggle stalwarts. In praising the women, it is to recognise the women as heroines in the freedom struggle.

The women in the struggle against the apartheid machinery were the powerless in society, and the apartheid machinery could have crushed them, as it did 20 years later on 16 June 1976, when about 20000 high school students protested against the use of Afrikaans in schools. Although the South African women were not issuing a literal threat to kill white people when they threatened Strijdom with death, they were not issuing an empty threat. It was a real threat and a prophetic utterance that anticipated the downfall of the apartheid-colonial machinery.

\section{Genesis 34 in dialogue with 2 Samuel 13: Hearing voiceless Dinah in Tamar's voice}

Genesis 34 and 2 Samuel 13 are, to use Phyllis Trible's classification (1984), 'texts of terror', with each telling a story of rape or sexual violence to a young woman not yet pledged for marriage. To use the isiZulu saying, it is the stories of uthintwa kwabafazi [the striking of women]. These two texts, as feminist scholars observe, are patriarchal texts that tend to portray women's lives and experience as subordinate to the lives and experiences of men, considering the patriarchal culture in which these texts were produced. However, inasmuch as the biblical texts are patriarchal, this does not exhaust their meaning potential. As Lapsley (2005:7) argues, 'neither implicit patriarchy nor even the explicit affirmation of patriarchal values exhaust the meanings of a narrative'. Voices of resistance to patriarchy may also be heard within the biblical texts (Brenner \& Van Dijk-Hemmes 1993; Claassens 2013; Exum 1993; Pardes 1992). However, in other instances, it is not the voice heard in the text, but the voice of resistance drawn into and from the text, considering the gaps and fissures in the text, which open room for other potential meanings.

Sexual violence against women - in whatever form or shape is not just something of the past or something described in the biblical texts; rather, it continues to happen even to this day. In the South African context, there is currently an ongoing rape trial in which several young ladies have 3.Translation: The name of women, let it be praised, Let it be praised; let it be praised. 4.Translation: The name of comrade Winnie be praised, Let it be praised; let it be praised. 
accused Pastor Timothy Omotoso of rape. ${ }^{5}$ The first witness was Cheryl Zondi, now 22 years old, who testified about the rape that happened to her when she was 14 years old. It is only now, eight years later, that she is able to give testimony of what happened to her when she was still a minor. In the cross-examination, Cheryl had to answer to questions from the defence lawyer in a way that forced her to relive the rape experience, even to the point of being questioned about how many centimetres the accused penetrated her vagina and about the opening and closing of her vagina during the rape.

Inasmuch as Cheryl was offering her own testimony of the violation of her body by a man that she trusted, it was and is a testimony with which other rape victims could identify. In Cheryl's experience, other victims could also see their own stories and could draw courage from her testimony. In raping Cheryl and other girls, Omotoso, in a sense, had struck the women and at the same time, he had struck a rock that will cause him to stumble. In taking a stand against Timothy Omotoso and testifying against this man, Cheryl not only spoke on her own behalf but also spoke on behalf of other women who have been sexually violated. In Cheryl's voice, they find their own voice.

\section{Shechem struck a woman: Hearing the voice of the voiceless Dinah in Tamar's story}

The rape of Dinah story has been the subject of discussion by scholars, and there are various opinions as to whether this is a rape story or not. Recently, Daniel Hankore in his book The Abduction of Dinah: Reading Genesis 28:10-35:15 as a Votive Narrative (2013), considering the Hadiyya people of Ethiopia's concept of vow and its affinities with the ancient Near Eastern cultures, has argued that the story of Dinah should be viewed as an adverse consequence of Jacob's failure to fulfil his vow to build the Lord a house in Bethel. In the Hadiyya culture, the Dinah story is regarded not as a rape story but as a story of ooki gosimma [marriage through abduction]: Shechem keeps Dinah and there is a negotiation for marriage (Hankore 2013:185-186). Hankore (2013:192-193) argues that in the case of rape, the driving force is the perpetrator's intention to satisfy his sexual desires and then abandon the victim, whereas, in the case of abduction marriage, deliberate steps are taken by the perpetrator to be known in order to secure consent.

In this study, however, I consider Genesis 34 and 2 Samuel 13 to be stories of the striking of a woman through rape. In the Genesis 34 story, Dinah is the female figure at the centre of the story; it is she who experiences sexual violence, and it is this experience in her life around which everything else revolves. Genesis 34:2 highlights the progression through the combination of verbs used (see Figure 1).

5.The rape trial of Timothy Omotoso was open for the public and broadcast. The recordings of the trial are available online on YouTube.

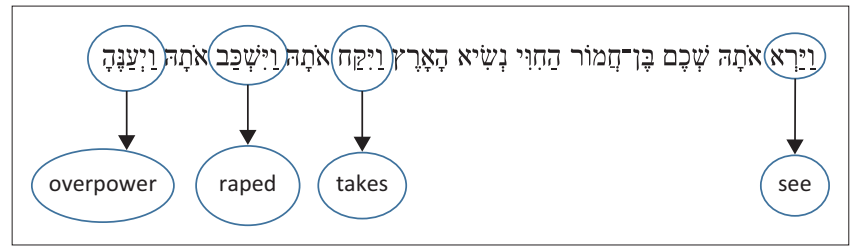

FIGURE 1: Genesis 34:2.

Thus, the verse may be rendered as:

Now, Shechem the son of Hamor, the Hivite, a prince of the land having seen her, he then took her and raped her, so he did by overpowering her.

The climactic moment in this verse happens when Shechem 'raped' (שכב (שכבה) (ענה) her (Dinah) and 'overpowering her'. The verb שכב is used in several instances for a sexual encounter between male and female (Gn 30:16, 35:22; 2 Sm 11:4; 13:14). Worthy for us to note is that the combination of these two verbs is also used to describe the sexual encounter between Amnon and Tamar, albeit in reverse, in 2 Samuel 13:14 (see Figure 2).

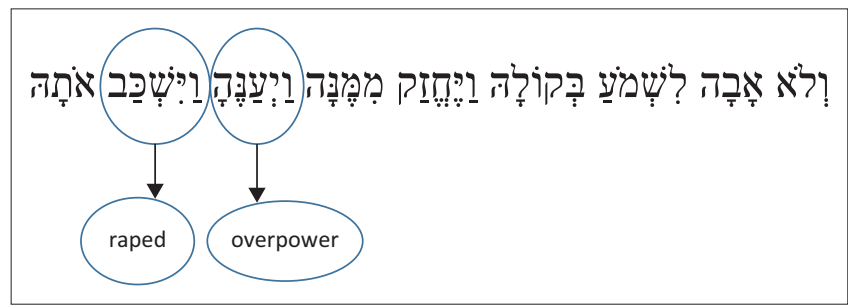

FIGURE 2: 2 Samuel 13:14.

This verse may be rendered:

But he [Amnon] refused to listen to her, and being stronger than she, he then overpowered her and raped her.

Considering Amnon's use of power in order to get Tamar to

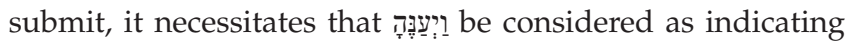
the imbalance of power between the two, as shown by the incorporation of the subject (he [Amnon]) and the object (her [Tamar]) in the one verb. Thus, the rape of Tamar was a process that involved force in order to overpower. This understanding of 2 Samuel 13:14, thus, should serve to enhance our understanding of Genesis 34:2. Although there is no reference in Genesis 34:2 to Shechem being stronger than Dinah, our understanding of וַיע in 2 Samuel 13:14 necessitates that Shechem's action be viewed as a sexual

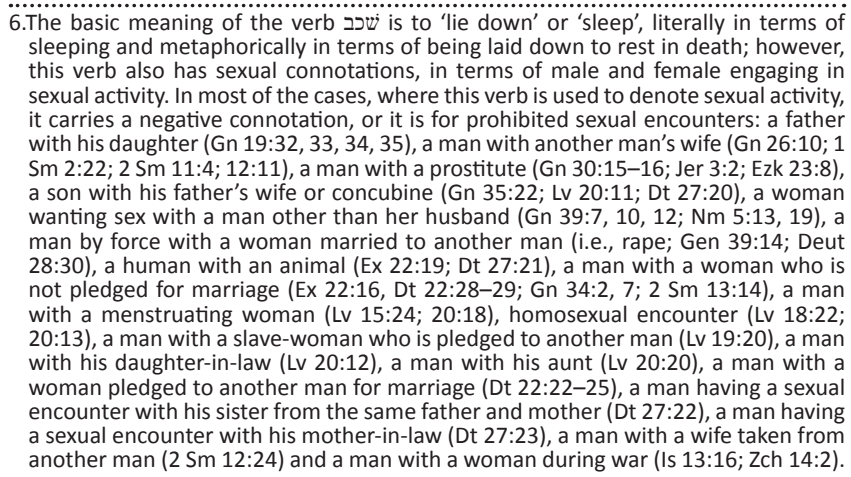


encounter through the overpowering of the weaker party, which necessitates that in both cases the verb שכב be viewed not as an innocent sexual encounter but as rape (Bar-Efrat 1989; Conroy 1978; Fokkelman 1981; Trible 1984:46). It may also be that, as others suggest, the Hebrew phrase

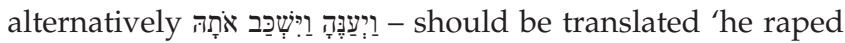
her', thereby combining the two concepts - overpowering and the sexual encounter - into one: rape (Noble 1996:178).

\section{Hearing Dinah: No, Do Not My Prince, Do Not Violate Me. ... Do Do Not Do Such a Disgraceful Thing}

In the story, all the other characters are given a voice except for Dinah. She is raped; however, she is not given a chance to speak. Instead, only the male characters speak in the story: Shechem (v. 4), Hamor (vv. 8-9), Shechem (vv. 11-12), the sons of Jacob (vv. 14-17), Shechem and Hamor (vv. 21-23), Jacob (v. 30), and Simeon and Levi (v. 31). These characters all speak in reference to Dinah. Dinah's life and experience are subordinated to the interest of the male characters. All the female characters in the story are given no voice they do not speak - Dinah herself, Leah (the mother of Dinah), and the unnamed women of the land. The silenced voice of Dinah is what is of interest to me, as I choose to listen to her silenced voice.

Although for others the silence or voicelessness of Dinah should not be the focus in interpreting this story, in my view, it is this gap that wreaks havoc with the story. As Blyth (2010:4) argues, 'the silence cloaking Dinah's persona thus becomes nothing less than a form of oppression, the mark of her narrative exclusion from honest representation within the text'.

The text projects three androcentric perspectives from two different cultures without necessarily endorsing any:

- Firstly, the perpetrators, the Hivites: The sexual violation of Dinah was motivated by love, and there was an intention to treat her well even after the violation by entering into negotiations for marriage.

- Secondly, one affected party, the Jacobites, the brothers of Dinah: Shechem's sexual violation of Dinah was כְבְלָה [grave sin, sacrilege] that rendered Dinah טָָמֵא [to be unclean] and treated her as a זٓנָז [prostitute].

- Thirdly, another affected party, Jacob, the father of Dinah: The gross violation of Dinah is something that can be overlooked for the sake of his own safety.

Even though the story of Dinah is projected to operate within patriarchal norms, gynocentric perspectives present in other biblical texts make it possible to reimagine this text from the gynocentric perspective. As Bauckham (1996:23) argues, 'Even though the majority of biblical narratives are androcentric narratives, there are enough authentically gynocentric narratives to counteract this dominant androcentricity, provided we allow them to do so' ${ }^{7}$ Therefore, 7.See also Bauckham (1996:29-45). the story of the rape of Tamar in 2 Samuel 13 presents a glimpse into the gynocentric perspective towards rape. It is particularly the words of Tamar that are of interest to us. Dinah is not given a chance to offer her perspective in Genesis 34 , but this does not imply that she did not have a view on what was happening. Dinah's experience comes alive in the rape story of Tamar, who tried to reason with her rapist, pleading with him not to rape her:

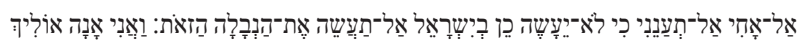
[No, my brother! Do not force yourself on me, for such a thing should not be done in Israel. Do not do this disgraceful thing. What about me? How could I get rid of the shame brought on me?]. (2 Sm13:12-13, [author's own translation])

In Tamar's words, I hear the words of Dinah. I paraphrase:

No, my prince! Do not force yourself on me, for such a thing is not done in Israel. Do not do this disgraceful thing. What about me? How could I get rid of the shame brought on me?

It is not unreasonable to speculate that in the interaction between Shechem and Dinah, the young woman would have made efforts to reason with Shechem to convince him to treat her with the dignity she deserved as a young woman. However, in the androcentric perspective of the Genesis 34 story, it is the brothers who are concerned about the 'shame' (חֶרפֶָה that the rape has brought on them and not about the 'shame' on their sister:

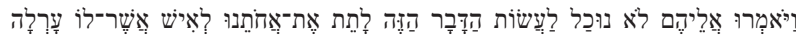
[They said to them: We cannot do this thing, to give our sister to a man who is not circumcised, for that will bring shame on us].

Considering the logic of the Genesis 34 story, there was a peaceful relationship between the Hivites and the Jacobites. Jacob had bought a piece of land from Shechem, a piece of land that had become their settlement. Furthermore, the ability of Dinah to go out to visit the women of the land also implied a two-way fluid relationship between the two groups. The story does not have to be understood as projecting events that all happened within a day; it describes events that happened over time. The likelihood is that Shechem observed Dinah over time and came to develop feelings towards her: 'His soul was drawn to Dinah the daughter of Jacob' (Gn 34:3). In my view, the logic of the story presumes that Shechem took deliberate steps to draw Dinah close to him before the rape incident: 'He loved her and spoke tenderly with her' (Gn 34:3). This does not imply that there may not be cases where rape can follow non-love. However, as argued, it does not seem to be the case in the rape of Dinah.

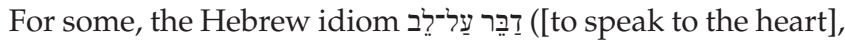
Gn 34:3; 50:21; Jdg 19:3; Rt 2:13; 2 Sm 19:8; 2 Chr 30:22; 32:6; Is $40: 2 ;$ Hs 2:16) was a way of Shechem to reassure Dinah and to win her loyalty after the rape, trying to get her to consent to the marriage (Fewell \& Gunn 1992: 196; Fretheim 1994:577; Frymer-Kensky 1998:90; Jeansonne 1990:138 n. 17; Kass 1992:32; Kass 2003:482; Scholz 2000:141). If this view is 
followed, this implies that in the case of Shechem the rape precedes the love, whereas in the case of Amnon the love precedes the rape; however, in the case of Amnon, after the rape, the love vanished. In my view, the story of Dinah seems to presume the 'beautiful wife/sister in the land of the other motif' (see Gn 12:13-20; 20:1-18; 26:1-8). ${ }^{8}$ In this motif, kings of foreign lands deemed themselves as having the powers to take beautiful foreign women who entered into their territory.

In the case of Tamar's rape, Amnon is drawn to his beautiful sister Tamar. However, Amnon did not have the royal powers just to take, and so he had to use deception in order to draw Tamar close before overpowering her and raping her. Although the Genesis 34 story does not detail, as the 2 Samuel 13 story, the tactics used to draw Dinah close, given the oppressive nature of states and the powers that kings had over those who came to their territories, it is not unreasonable to assume that the prince Shechem could have marshalled the state servants to apprehend Dinah. In the case of Sarah and Rebekah, three incidences are reported of kings taking the beautiful women who come to their territory: firstly when Abram and Sarai went to Egypt, when state officials praised Sarai for her beauty to the Pharaoh, she was taken to the king; and secondly, the case of Abimelech, king of Gerar, who sent for Sarah and took her, and thirdly, the case of Rebekah who although not taken, Abimelech, king of Gerar, expressed the idea that she could have been taken.

Although Dinah could have attempted to speak words of wisdom to Shechem, we know from Tamar's rape story that rapists are more interested in satisfying their own sexual desires than caring about the well-being of another person. Yamada rightly argues that 'the reader must ponder the appropriateness of Shechem's affection'; however, pace Yamada, not so much because the relationship began with sexual violence; rather, as Blyth (2010) argues:

Shechem's apparent feelings of desire and attachment for Dinah are by no means laudable, nor should they elicit our sympathy for him. If anything, they should heighten our sense of disdain and loathing for this man, who, despite subjecting a woman to the most terrible of ordeals, appears to have little or no insight of the wrongfulness of his actions. (p. 219)

In my South African context, the rape of Dinah evokes the Omotoso rape trial, in which the accused targeted young girls who joined the church by presenting them with opportunities within the ministry to sing, to travel and to stay in luxurious houses and then raping them when they were trapped in the system. However, there remains a lingering tendency to be suspicious of the victims of rape and sexual violence. Such a tendency is also reflected in the way that some have interpreted Dinah's actions as those of a young woman who placed herself in danger by

8.The difference between the Dinah story and the other stories is that Dinah is unmarried and there is no mention of her beauty; futhermore, considering the deveront in the book of Genesis - the family of the patriarch Jacob is longer just development in the book of Genesis - the family of the patriarch Jacob is longer just a nuclear family of husband and wife/wives, somewhat the family had grown into clan. However, as in the other story, it is the royal figure who is interested in the woman in their territory and takes. leaving the confines of her father and her own community (Frymer-Kensky 2002:180; Graetz 1993:312; Kass 2003:479; Leupold 1942:898; Parry 2004:231-232; Sarna 1989:233; Von Rad 1972:331). It is this kind of character assassination of victims that occurred when Cheryl Zondi's character was being assassinated by the defence team, which tried to portray her as a foolish young lady who willingly and voluntarily placed her life in a dangerous venture not just once but twice.

The fact that Dinah is rendered voiceless in the Genesis 34 story but the male characters are given time to voice their opinions does not imply that she was raped in silence. Considering the 2 Samuel 13 narrative, Dinah would have embodied a spirit similar to that of Tamar, the bold spirit of looking straight into the eyes of the perpetrator and telling it as it is:

No, do not, because my life matters, and it matters in my community as well.

Neither does the voicelessness of Dinah imply that she had no high moral values, nor that she was less concerned about her dignity as a woman. Shechem, by striking Dinah, had struck a rock that would cause him to stumble: not just him, but his people as well.

\section{Hearing the voice of Dinah: Shechem, you were warned}

In reading the Genesis 34 story, some scholars tend to read Shechem's character positively by regarding Shechem as acting out of love (Fretheim 1994:574-581; Sheresh 1990:85; Scholz 1998:171; Frymer-Kensky 2002:189). In this view, Shechem's marriage proposal after the rape is regarded as an exoneration considering the law code in Exodus 22:15-16 and Deuteronomy 22:28-29 (Fischer 1994). Bechtel argues that Shechem and his father Hamor are honourable men and that the sexual encounter between Shechem and Dinah was not shameful but was intended to strengthen the social bond between the two communities (Betchel 1994).

Shechem's move to negotiate a marriage to Dinah following the rape should not be viewed as an innocent move of obedience to the common law of rapist-victim marriage, but as a move that stems from the warning Dinah gave him in an attempt to correct his foolishness. This is analogous to Tamar's warning to Amnon:

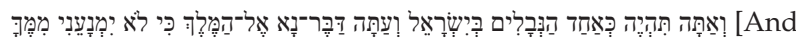
as for you, you will be like one of the disgraceful in Israel. Now, therefore, please speak to the king, for he will not withhold me from you].

In the words of Tamar, we should hear Dinah's voice as well. I paraphrase:

And as for you [Shechem], you will be like one of the disgraceful in Israel. Now, therefore, please speak to my father, for he will not withhold me from you. 
Although Genesis text projects Shechem's action of seeking to negotiate marriage as motivated by love towards the victim, beyond that Shechem's negotiation of marriage has to be viewed as a response to Dinah's words. What Shechem had done was a disgraceful thing in Dinah's community. The account in Genesis 34 is more emphatic in describing the act of rape than is that in 2 Samuel 13, stating as it does

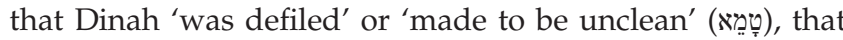

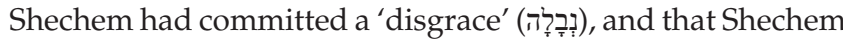
had treated Dinah as 'a prostitute' (זָנָה).

Amnon's rape of Tamar is considered 'a disgraceful thing in

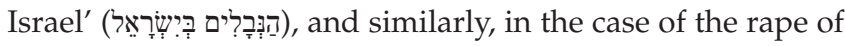
Dinah, the brothers of Dinah consider what Shechem did to be a disgraceful thing in Israel:

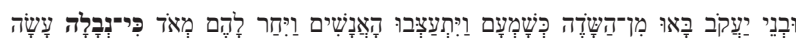

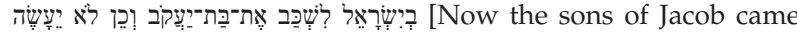
from the field when they heard, and the men were grieved, and they were very angry because he had done a disgraceful thing in Israel by raping Jacob's daughter, for such a thing ought not to be done]. (Gn 34:7)

In the Genesis 34 story, what Shechem had done to Dinah is considered a disgraceful thing, and so in a sense, using Tamar's words, Shechem had become 'like one of the

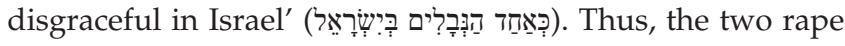
stories enrich each other, therefore offering us a broader perspective on the rape of young women not pledged for marriage.

Rape of young women not pledged for marriage should thus be viewed as unacceptable, whether done by an insider within the house of Israel like Amnon or by an outsider like Shechem; furthermore, it is unacceptable whether the love precedes the rape as in the case of Amnon or the love follows the rape as in the case of Shechem. Shechem's attempt to negotiate marriage following the rape could not, in light of 2 Samuel 13, reverse the damage already done not just to Dinah, but to his character as well.

How could someone who had become a disgrace in Israel hope that he would successfully negotiate marriage? Shechem should be viewed as someone who condemned himself not by his attempt to do the right thing by marrying Dinah, but rather by not heeding her voice of wisdom; he condemned himself by raping the young lady and then by entering into the negotiation of marriage after the fact. Thus, reading against the grain, we can hear a voice that undermines the vocal androcentric perspectives on Genesis 34 by affirming the dignity of women.

In 2 Samuel 13:16, following her rape, Tamar suggests to Amnon that he not send her away, as that would be an

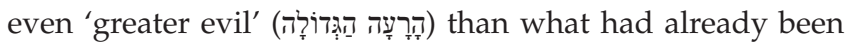
done to her. However, the rapist, Amnon, was not willing to listen to such a call. Tamar's words evoked the law code, which provided that a rape victim who is not yet pledged for marriage should be married by her rapist never to be divorced (Ex 22:15-16; Dt 22:28-29). The rape of Tamar story is a clear indication that that law was immoral, pointing to the injustice of letting a rapist get away with a crime of violating young women who are not yet pledged to be married as if their lives did not matter as much as the lives of young women who are pledged for marriage. The law, inasmuch as it was intended to regulate human behaviour, was not entirely successful, and its application could be undermined in more ways than one.

The rape of Dinah narrative, inasmuch as it is presented as preceding the law code, serves intertextually to undermine the rapist-victim marriage law. By having the brothers claiming that such a disgraceful thing cannot be done in Israel, the Dinah story thus presents an alternative to the rapist-victim marriage. Thus, in the case of Genesis 34, it is the community that undermines the law code, whereas in the 2 Samuel 13 narrative, it is the rapist who undermines the law code. The two stories of rape of young women not pledged for marriage, therefore, points to the failure of the simplistic law code, which does not take into consideration all the complex dimensions involved in such rape cases.

\section{Uzakufa [You will die]}

In the two rape stories, the two women, Dinah and Tamar, are not granted room to express what they felt should be done with the rapist; however, in both stories, the rapist dies a violent death. In their stories, Dinah and Tamar - unlike the women of South Africa who shouted, Uzakufa! [You will die] at the apartheid machinery that oppressed them - do not offer any prophetic utterance.

In the Genesis 34 passage, the brothers are presented as if they were in agreement with the gravity of what Shechem had done to their sister, Dinah, and the consequence thereof; however, it was only two brothers (Simeon and Levi) who were willing to follow through and engage in a mission to rescue their sister Dinah, which they couched in deception with the aim of killing Shechem and all the men in his city, and plundering the city by taking the property and women and children.

The actions of the two brothers, Simeon and Levi, has resulted in scholars regarding the main point of the Genesis 34 story not as the rape of Dinah but as the rape of Shechem, considering the gravity of the crime committed by the two brothers as compared to the crime done to only one person, Dinah. ${ }^{9}$ The crime of Shechem and the crime of the two brothers, Simeon and Levi, both deserve to be condemned. However, in the rape of Dinah story, the patriarch, Jacob, in his speech condemns the actions of the two brothers and is concerned with his own safety. The words of the patriarch Jacob, inasmuch as they are presented as authoritative, condemn the brothers; however, the reader cannot overlook

9.Van Wolde (2002:237) states, 'As bad as rape is the prohibition of free movement, of having on's own perspective, and the denil of speech, because it makes people invisiblo and disappears frome, and the denial of speech, because it makes people invisible and disappears from our memories. Worse than rape, however, is genocide on a people, the slaughter of all men and the capturing of all the women and children. And Dinah is held responsible for it. The first and last words of the tex show that the blame falls on Dinah'. 
or brush aside the patriarch's own concern for his interests and safety. The patriarch is presented as a figure who regarded the virginity of his daughter as an 'exchangeable commodity' that could be compensated for through financial means or otherwise $\mathrm{e}^{10}$ and condemned his daughter into a rapist-victim marriage. The patriarch wanted to benefit from the longterm relationship between Shechem and Dinah in which the two parties stood to benefit. Thus, Jacob acted like the other patriarchs, Abraham, Lot, and Isaac, who were willing to use the women in their lives as bargaining tools in order to save their own necks. In Jacob's speech, it is not the anguish and plight of his daughter that is of concern but his own safety in the land for which he would rather collude with the rapist (Blyth 2010:118; Sheresh 1990:73).

Dube (2017), reading the Dinah story from a postcolonial framework, regards the brothers' insistence that their sisters should not be treated as a whore as an indication of the brothers' colonial mentality, which rejected equality between the two parties by projecting the Shechemites/Hivites as immoral. The treatment of Shechem fits with the colonial conquest ideology, which is reflected in the patriarchal narratives in which the patriarchs are travelling heroes who plunder the resources of the targeted foreign lands. Although Dube's concerns are legitimate, it not necessary that the plight of the one should be overlooked, as it is the neglect of the plight of the one which often leads to even graver injustices in society. Injustice remains injustice, even if it is inflicted on one person; it cannot be that justice should only be sought where the many are involved. I am reminded here of the New Testament words of the apostle Paul that point to the connection between the one and the many: 'But the free gift is not like the trespass. For if many died through one man's trespass, much more have the grace of God and the free gift in the grace of that one man Jesus Christ abounded for many' (Rm 5:15 RSV).

The story of the rape of Dinah prefigures the story of the rape of Tamar. In the rape of Tamar story, just as in the Dinah story, Tamar offers no judgment on the rapist, Amnon; however, the rapist dies a violent death, killed by her brother Absalom. In addition, the father, who is made aware of the rape, is furious but does nothing; instead, he mourns when the rapist is killed. However, in the Tamar story, unlike in the Dinah story, the reader is given a glimpse into her post-traumatic experience - she lived as a desolate woman in her brother's house (2 Sm 13:20). Her voice is never heard again; however, her name has lived on, as Absalom named his daughter Tamar; this is unlike Dinah, who is never heard from again.

Although Dinah and Tamar do not utter the word uzakufa, their stories scream. The Deuteronomic legislation concerning the rape of women not pledged for marriage uttered to the rapist is Uzaphila [You will live]. The law code in Exodus 22:16-17 gave the father the right to refuse the rapist the right 10.See Washington (2004:211). to marry his daughter. However, in Dinah's story, the father (Jacob) was not interested in protecting the right of his daughter; rather, he was concerned about his own selfinterest. However, the thought of young rape victims living with their rapists probably eroded in ancient Israel society over time. An alternative view had to be presented - the rapist had to die. The law had to be broken.

Inasmuch as the deaths of the Hivites and Amnon may be viewed as unfortunate, the two rape stories in some sense reflect the self-destructive tendencies that come as a result of the neglect of justice towards women at the margins and centre of society. Dinah represents women at the margins of society, whereas Tamar represents women at the centre of society. The unjust treatment of women in society, whether at the margins at the centre, destroys society.

\section{Conclusion}

The rape stories of young virgins who are not pledged for marriage, Dinah and Tamar, in Genesis 34 and 1 Samuel 13, should not be viewed simply as stories of victims of rape. The stories of these two women set them as heroines in the canonical story - the women whose stories challenged the legislation of the land. Dinah's rape story is shouted out loud in the story of the rape of Tamar. In her silence, Dinah is the stone rejected by builders that has become a cornerstone. Dinah's suffering can be heard from other women who open up about their ordeal. Thus, the two stories should be viewed as protest stories of the rapistvictim marriage law, which undermined the dignity of women in ancient Israel.

The young woman who calls me each year and says, 'It was on this day that it happened' has not had her day in court to testify about the terrible ordeal that she went through on that fateful day, as her rapist is still on the loose - or perhaps he is dead already. However, the ordeal that she suffered not only came from the hands of her rapist, but also from those who chose not to believe her or blamed her for the rape. However, this young woman has dared to tell her story and overcome the desolation of Tamar. Her voice shouts, Wanthint' umfazi, wathint' imbokodo, uzakufa! In her voice, the voice of the voiceless Dinah comes to life, and the voice of Tamar shouts even louder: 'My life matters! Her life matters! Our lives matter!'

In conclusion, I sing:

Igama lamakosikazi, malibongwe,

Malibongwe, malibongwe.

Igama le ka Dinah,

Malibongwe, malibongwe.

Igama le ka Tamar,

Malibongwe, malibongwe.

Igama le ka Cheryl Zondi,

Malibongwe, malibongwe. 


\section{Acknowledgement Competing interest}

The author declares that they have no financial or personal relationships which may have inappropriately influenced them in writing this article.

\section{Author contributions}

H.R. is the sole contributor to this article.

\section{Ethical considerations}

This article followed all ethical standards for carrying out research without direct contact with human or animal subjects.

\section{Funding}

This research received no specific grant from any funding agency in the public, commercial, or not-for-profit sectors.

\section{Data availability statement}

Data sharing is not applicable to this article as no new data were created or analysed in this study.

\section{Disclaimer}

The views and opinions expressed in this article are those of the authors and do not necessarily reflect the official policy or position of any affiliated agency of the authors.

\section{References}

Bakhtin, M., 1981, The dialogic imagination: Four essays, transl. C. Emerson \& M. Holquist, M. Holquist (ed.), University of Texas, Austin, TX.

Bar-Efrat, S., 1989, Narrative art in the Bible, Almond Press, Sheffield.

Bauckham, R., 1996, Is the Bible Male? The book of Ruth and Biblical narrative, Grove Books, Cambridge.

Bechtel, L.M., 1994, 'What if Dinah is not rape? (Genesis 34)', Journal for the Study of the Old Testament 64, 19-36. https://doi.org/10.1177/030908929401906202

Blyth, C., 2010, The narrative of rape in Genesis 34: Interpreting Dinah's silence, Oxford University Press, Oxford.

Brenner, A. \& Van Dijk-Hemmes, F., 1993, On gendering texts: Female and male voices in the Hebrew Bible. BIS 1, Brill, Leiden.

Claassens, J., 2013, 'Female resistance in spite of injustice: Human dignity and the daughter of Jephtha', Old Testament Essays 26(3), 607-622.

Cock, J., 1991, Colonels and cadres: War and gender in South Africa, Oxford University Press, Cape Town.

Conroy, C., 1978, Absalom, Absalom!: Narrative and Language in 2 Sam. 13-20, Biblical Institute Press, Rome.

Dube, M., 2017, 'Dinah (Genesis 34) at the contact zone: Shall our sister become a Whore?' in Feminist frameworks and the Bible: Power ambiguity and intersectionality, L.J. Claasens \& C.J. Sharp (eds.), pp. 39-57, Bloomsbury, London.

Exum, C., 1993, 'On Judges 11', in A feminist companion to Judges, A. Brenner (ed.), pp. 131-145, Sheffield Press, Sheffield.

Fewell, D.N. \& Gunn, D.M., 1992, 'Tipping the balance: Sternberg's reader and the rape of Dinah', Journal of Biblical Literature 110(2), 193-211. https://doi.org/ $10.2307 / 3267082$

Fischer, I., 1994, Die Erzeltem Israel: Feministich-Thoelogische Studien zu Genesis 12-36, De Gruyter, Berlin

Fokkelman, J.P., 1981, King David, volume I of narrative art and poetry in the books of Samuel, Van Gorcum, Assen.
Fretheim, T.E., 1994, 'The book of genesis: Introduction, commentary, and reflections', in L.E. Keck (ed.), New Interpreter's Bible, pp. 319-674, Abingdon Press, Nashville, TN.

Frymer-Kensky, T., 1998, 'Virginity in the Bible', in Gender and law in the Hebrew Bible and the ancient Near East, V.H. Matthews, B.M. Levinson \& T.S. Frymer-Kensky, pp. 79-96, Sheffield Academic Press, Sheffield.

Frymer-Kensky, T., 2002, Reading the women of the bible, Schocken Books, New York.

Gilbert, S., 2005, 'Popular song, gender equality and the anti-apartheid struggle', in C. Walton \& S. Muller (eds.), Gender and sexuality in South African music, pp. 11-18, SUN, Stellenbosch.

Gouws, A. \& Kadalie, R., 1994, 'Women in the struggle: The past and the future', in I. Liebenberg, F. Lortan, B. Nel \& G. Van der Westhuizen (eds.), The long March: The story of the struggle for liberation in South Africa, pp. 213-226, Haum, Pretoria.

Graetz, N., 1993, 'Dinah the daughter', in A feminist companion to genesis, A. Brenner (ed.), pp. 306-317, Sheffield Academic Press, Sheffield.

Hankore, D., 2013, The abduction of Dinah: Reading genesis 28:10-35:15 as a votive narrative, Pickwick, Eugene, OR.

Jeansonne, S.P., 1990, The women of genesis: From Sarah to Potiphar's Wife, Fortress Press, Minneapolis, MN.

Kaim, B., 1978, 'The surgery: The illicit liqour problem on the Rand, 1920-1945', Sociology III Project, University of the Witwatersrand, Johannesburg.

Kass, L., 1992, 'Regarding daughters and sisters: The rape of Dinah', Commentary 93(4), 29-38.

Kass, L., 2003, The beginning of wisdom: Reading genesis, Free Press, New York.

Kros, C., 1978, 'Urban African women's organisations and protests on the rand from the years 1939-1956', B.A. Honours Dissertation, University of Witwatersrand.

Lapsley, J.E., 2005, Whispering the word: Hearing women's stories in the Old Testament, Westminster John Knox Press, Louisville.

Leupold, H.C., 1942, Exposition of genesis, Evangelical Press, London.

Meintjes, S., 1996, 'The women's struggle for equality during South Africa's transition to democracy', Transitions 30, 47-64.

Noble, P., 1996, 'A "Balanced" reading of the rape of Dinah: Some exegetical and methodological observations', Biblical Interpretation 4(2), 173-203. https://doi. org/10.1163/156851596X00185

Nzimande, M.K., 2005, 'Postcolonial biblical interpretation in post-apartheid South Africa: The Gebirah in the Hebrew Bible in the Light of Queen Jezebel and the Queen Mother Lemuel', PhD dissertation, Brite Divinity School, Texas Christian University.

Nzimande, M.K., 2008, 'Reconfiguring Jezebel: A Postcolonial Imbokodo Reading of the Story of Naboth's Vineyard (1 Kings 21:1-16)', in African and European readers of the Bible in dialogue: In quest of a shared meaning, H. De Wit \& G.O. West, pp. 223-258, Brill, Leiden.

Obery, I., 1980, 'Makabongwe Amakosikazi! The FSAW and Mass Struggle in the 50's', Africa Perspective 15(Autumn), 36-41.

Pardes, I., 1992, Countertraditions in the Bible: A feminist approach, Harvard University Press, Cambridge.

Parry, R., 2004, Old Testament story and Christian Ethics: the rape of Dinah as a case study, Paternoster Press, Milton Keynes.

Pollard, A.B., III, 1999, 'Rhythms of resistance: The role of freedom song in South Africa', in This is how we flow: Rhythm in black cultures, A.M.S. Nelson (ed.) pp. 98-124, University of South Carolina Press, Columbia.

Sarna, N., 1989, Genesis: The traditional Hebrew text with the New JPS translation, Jewish Publication Society, Philadelphia, PA.

Sheresh, I., 1990, Dinah's rebellion: A biblical parable for our time, Crossroads, New York.

Scholz, S., 1998, 'Through whose eyes? A "right" reading of genesis 34', in Genesis: A feminist companion to the Bible, A. Brenner (ed.), pp. 150-171, Sheffield A feminist companion to

Scholz, S., 2000, Rape plots: A feminist cultural study of genesis 34, Peter Lang, New York.

Trible, P., 1984, Texts of terror: Literary-feminist readings of biblical narratives, Overtures to Biblical Theology, Fortress Press, Philadelphia, PA

Van Wolde, E., 2002, 'The Dinah Story: Rape or worse?' Old Testament Essays 15(1), 225-237.

Von Rad, G., 1972, Genesis: A commentary, transl. J.H. Marks, SCM Press, London.

Walker, C., 1978, 'Women in twentieth century South African politics: The Federation of South African Women, its roots, growth and decline', M.A. Thesis, University of Cape Town.

Walker, C., 1991, Women and resistance in South Africa, 2nd edn., David Philip Publishers, Claremont, CA.

Washington, H.C., 2004, "'Lest he die and another man take her": Violence and construction of gender in the laws of Deuteronomy 20-22', in Gender and law in the Hebrew Bible and the Ancient Near East, V.H. Matthews, B.M. Levinson \& T. Frymer-Kensky, pp. 185-213, Sheffield Academic Press, Sheffield, 1998; reprint New York: T\&T Clark.

Wells, J.C., 1993, We now demand: The history of women's resistance to pass laws in South Africa, Witwatersrand University Press, Johannesburg. 